\begin{tabular}{l|c|c|}
\hline DE & DE GRUYTER \\
$\mathrm{G}$ & EPEN & ECONOMIC THEMES (2017) 55(2): 243-262 \\
\hline
\end{tabular}

\title{
AN ANALYSIS OF THE RELATIONSHIP BETWEEN JOB SATISFACTION AND EMPLOYEE ENGAGEMENT
}

\author{
Anton Vorina \\ School of Economics, Higher Vocational College, Celje, Republic of Slovenia \\ 凶saitonci1@gmail.com \\ Miro Simonič \\ Faculty of Commercial and Business Sciences, Celje, Republic of Slovenia \\ $\bowtie$ mirosimoni@gmail.com
}

Maria Vlasova

Faculty of Economics, Russian Customs Academy,Russia

$\triangle$ mariavlasova555@mail.ru

UDC

005.311.12

1

Original scientific paper
Received: 22.08.2016. Accepted: 25.04.2017.

\begin{abstract}
This paper examines the relationship between employee engagement and job satisfaction. People spend most of their time at work, and their motivation is considered to be an important factor for job performance. Enthusiastic employees, who focus their efforts on achieving their companies' goals are a key competitive advantage in the modern world. The effect of employee engagement on business performance has been studied by various experts. They found out the similar conclusion: "the more enthusiastic the workers are, the better operating results they achieve for the company". An occasional sample of 594 respondents who are employed in the public and non-public sector in Slovenia was used for the purpose of this study. The main goal of the research is to determine whether (and how) the employee engagement influences job satisfaction. A written survey was conducted from 4 January 2016 to 14 March 2016. IBM SPSS 20 was used for the statistical analysis. The results confirm that the relationship between employee engagement and job satisfaction is positive and statistically significant (5\% significance level), based on the linear regression $\mathrm{F}$ (1, $583)=296.14, \mathrm{p}$-value $=0.000, \mathrm{R}$-square $=0.337$. The results also show that there is no statistically significant difference between employee engagement and gender and there is no statistically significant difference between job satisfaction and gender.
\end{abstract}

Keywords: employee, engagement, job satisfaction, linear regression, factor analysis.

JEL classification:J28 


\section{Introduction}

The purpose of this paper is to investigate whether and how one variable (engagement of employees-EE) influences the dependent variable under study defined as Y-a (job satisfaction-JS). The main research hypothesis is that the independent variable (X-EE) explains the variation in variable (Y-JS) and this explanation is statistically significant.

The additional research hypothesis states that there is a statistically significant difference in the employee engagement between genders.

The last research hypothesis states that there is a statistically significant difference in job satisfaction between genders.

The following programmes were used for the analysis: IBM SPSS 20 and Excel. The ANOVA test and the linear regression model were applied for the analysis. Research data has been acquired through the use of a questionnaire.

The definition companies are employees notifies how important it is, that employees are satisfied with their job. Only satisfied employees can be creative and able to keep the pace dictated by the contemporary labour market. These employees help their companies resist the competition that is coming from a global market. Many companies are already aware of this fact and this is why more specialists evaluate and monitor the level of employee satisfaction with their job. Scientific institutions, that were looking into factors, that influence satisfaction of employees with their position, started to carry out research. Today, these researches are the most massively executed ones in the world.

Satisfaction of employees (Job satisfaction-JS) is an emotional condition of the individual about his/her position at work (Warr \& Inceoglu, 2012). The final effect of his/her work depends on his/her satisfaction, which is expressed in profit that the employee creates. Additional factors that are very closely connected with satisfaction are absenteeism and fluctuation. These two factors directly influence successful development and efficiency of a company.

Psychologists started to carry out researches about satisfaction with job position in the early twenties of the twentieth century. One of the first researches of this kind was carried out in the unit of a Western Electric Company and showed that working productivity increased regardless of change of physical points of view of the worker, and despite of the negative conditions (less light, shorter pauses, extended working hours) (Roethlisberger \& Dickson, 1939). By the end of the last century the researches of this kind expanded and more environmental and individual factors were under study. The goal of the researches was to find better ways to influence working productivity. Communications about the job position, care for the safety of the occupation, length of occupation and satisfaction judge among the first factors with rate of variability in an organisation. Other individual 
factors are the influence of genetics (Staw, Bell and Clausen in Landy and Conte, 2007), emotions (Grandey 2000), personalities (Brief and Weiss, 2002) and rudiment of basic evaluation (Judge and Bono, 2001) on satisfaction at work.

The measurement of the employee satisfaction at work requires careful observation of their opinion, feelings and experience within the working environment. Kelloway and Iverson (2003) proved in their study that satisfaction with work was connected to small numbers of injuries at work.

It is possible to carry out observation from an employer's point of view. Harter, Schmidt and Hayes (2002) proved a positive correlation between job satisfaction and productivity, profit, safety and fluctuation of employees. Schneider as well as Hanges and Salvaggio (2003) found out that the success of an organisation increases general satisfaction with work and strongly increases correlation between joy and productivity at work. Even events outside of the workplace influence job satisfaction. Brief and Weiss (In 2002) found out that employees already came to work in mood that had been already influenced by certain factors. Satisfaction of employees is often measured with multidimensional questionnaires with ranking and sub-scales. Job satisfaction may include different points of view, such as possibilities for advancement, working circumstances, relations with collaborators, age of occupation, reputation and salary. A chart for assessment within a questionnaire must be simple and understandable for every respondent (Pogačnik, 2002). The questionnaire measures satisfaction with work in different professions and with different conditions such as working conditions, advancement, diversity of works, direction, social status, safety, mutual help, authority, creativity at part, collaboration, working success, praises and confessions, payment, responsibility, rules and procedures of the company.

Recently, research carried out by Semih and Tugba (2016) compared the change of standard deviation between satisfaction with the job position and satisfaction with the local level of the labour market. The findings show that a change in satisfaction with the position is approximately three times larger than a change in satisfaction with the local level of the labour market.

So far the first empirical research by Fleischer, Khapova and Jansen (2014) from a university in Netherlands, studied the connection between the development of employees professional competences and the contribution of employees to their employers success. They found out, that if employers invested in the development of professional competences of employees, this would contribute to the organisational culture, would increase the capacity, and the quality of the internal communications.

With a questionnaire, based on template SERVQUAL, Lee (2006) says this study aims to prove that a connection between job satisfaction and working results of the employees exists. Lee was interested in how employees were physically 
detecting their working environments and what they expected from their job. Based on the results of the regression analysis, he found that bad physical conditions lead to dissatisfaction of employees, meanwhile more suitable physical conditions do not contribute to reaching the expected levels of employees' satisfaction. Other factors that influence satisfaction of employees have differently profound influence on the behaviour and the feelings of employees. Because satisfaction of employees at work depends on their current mood, it is necessary to include extremely large sample and to finish the research within extremely short time in order to get correct findings based on the gathered data. Longitudinal researches carried out in the same time periods provide more reliable results. A research has to define common points, which represent homogeneity of a group. If more companies and institutions are studied, it would be interesting to make a comparison between superior and inferior groups and evaluate how much these two groups are differently satisfied with their job positions. Many results of previous researches indicated that findings were different than the expected logical hypotheses. Comparison between satisfaction with the job position between management and common employees is of course very interesting for further researches.

\section{Theoretical Background}

Kahn (1990, p. 694) was the first scholar to define personal engagement as the "harnessing of organization member's selves to their work roles: in engagement, people employ and express themselves physically, cognitively, emotionally and mentally during role performances."

Employee Engagement is your employees' ability and willingness to contribute to organisational success, especially their willingness to give discretionary effort, going beyond what is typically required in their position to make the organisation successful.

The model below highlights the elements of developing and maintaining an engaged workforce. Employee Engagement is an essential element of organisational health and is the goal of strategic initiatives designed to improve employee attitudes and retention through leadership, co-workers, job/career satisfaction, and a high performing organisation. Increase your impact and energise your engagement and retention efforts. Our knowledge, solutions, capability and experienced team makes Talent Keepers your best partner (Figure 1). 
Figure 1. Engage emloyees

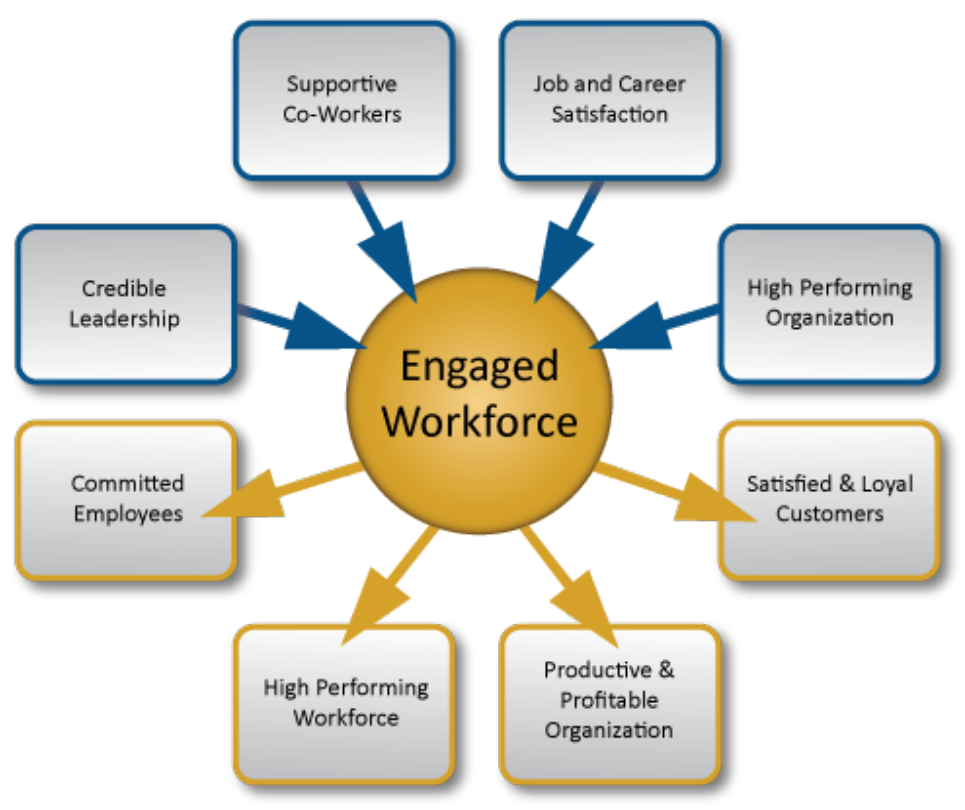

Source:http://www.talentkeepers.com/engagement.jsp

Employee Engagement is above all average willingness to engage the energy and commitment of all employees in everything they do in order to achieve outstanding results (http://www.dialogos.si/slo/objave/clanki/zavzetost/).

Employee Engagement, also called worker engagement, is a business management concept. "Employee Engagement is a measurable degree of an employee's positive or negative emotional attachment to their job, colleagues and organization that profoundly influence their willingness to learn and perform is at work" (Shanmuga \& Vijayadurai, 2014). Work engagement has been defined as "a positive, fulfilling work-related state of mind that is characterized by vigour, dedication, and absorption” (Schaufeli et al., 2006, p. 702). Employee Engagement is a distinct and unique construct that consists of cognitive, emotional, and behavioural components that are associated with individual role performance (Saks, 2006). Work engagement is defined as a positive, fulfilling, work-related state of mind that is characterised by vigour, dedication, and absorption (Schaufeli et al., 2002). Maslach et al. (2001) noted that engagement is characterised by energy, involvement, and efficacy - the direct opposites of the three burnout dimensions, exhaustion, cynicism and ineffectiveness.

Employee Engagement is a workplace approach designed to ensure that employees are committed to their organisation's goals and values, motivated to contribute to organisational success, and are able at the same time to enhance their 
own sense of well-being. There are differences between attitude, behaviour and outcomes in terms of engagement. An employee might feel pride and loyalty (attitude); be a great advocate of their company to clients, or go the extra mile to finish a piece of work (behaviour). Outcomes may include lower accident rates, higher productivity, fewer conflicts, more innovation, lower numbers leaving and reduced sickness rates. But we believe all three - attitudes, behaviours and outcomes - are part of the engagement story. There is a virtuous circle when the preconditions of engagement are met when these three aspects of engagement trigger and reinforce one another. Engaged organisations have strong and authentic values, with clear evidence of trust and fairness based on mutual respect, where two ways promises and commitments - between employers and staff - are understood, and are fulfilled (http://www.engageforsuccess.org/about/what-isemployee-engagement/).

Vorina's (2013) study shows that the engagement of employees would increase if the satisfaction with life increased. Vorina, David, Vrabič-Vukotić (2013) study shows that if the development of ICT skills increased than the employee engagement would also increase. The results of the study (Rathi, 2011) demonstrated a positive relationship between psychological well-being and organisational commitment and its components, namely affective, continuance, and normative commitment. In the literature, occurr two completely different questionnaires for measuring employee engagement. Gallup Institute measures engagement of employees with 12 claims, Saks (UWES-9) and other measures with 9 claims.

In short, the development of the Gallup questionnaire was based on more than 30 years of accumulated quantitative and qualitative research. Its reliability, convergent validity, and criterion-related validity have been extensively studied. It is an instrument validated through prior psychometric studies as well as practical considerations regarding its usefulness for managers in creating change in the workplace. The $\mathrm{Q}^{12}$ statements are (Harter, Schmidt, Killham, \& Asplund, 2006):

G1. I know what is expected of me at work,

G2. I have the materials and equipment I need to do my work right,

G3. At work, I have the opportunity to do what I do best every day,

G4. In the last seven days, I have received recognition or praise for doing good work,

G5. My supervisor, or someone at work, seems to care about me as a person,

G6. There is someone at work who encourages my development,

G7. At work, my opinions seem to count,

G8. The mission or purpose of my company makes me feel my job is important, 
G9. My associates or fellow employees are committed to doing quality work,

G10. I have a best friend at work,

G11. In the last six months, someone at work has talked to me about my progress,

G12. This last year, I have had opportunities at work to learn and grow (http://www.gallup.com/strategicconsulting/126806/q12-meta-analysis.aspx).

This scale, called the Utrecht Work Engagement Scale (UWES) is composed of 9 items and was found to have good psychometric properties, with Cronbach's $\alpha$ generally higher than 80. TheUWES-9 (Schaufeli\& Bakker, 2003) questionnaire consists of 9 items:

S1. At my work, I feel bursting with energy,

S2. At my job, I feel strong and vigorous,

S3. I am enthusiastic about my job,

S4. My job inspires me,

S5. When I get up in the morning, I feel like going to work,

S6. I feel happy when I am working intensely,

S7. I am proud of the work that I do,

S8. I am immersed in my job,

S9. I get carried away when I am working.

\section{Research Methodology, Results and Discussion}

Sample: For this research the authors selected population - residents / in the Savinja Statistical Region in Slovenia. The investigated unit were people over 16 years old employed in the enterprise or an institution. The sampling frame consisted of residents / s from different places and towns in the Savinja Statistical Region. The sample consists of 594 respondents. The study included 251 (42.5\%) men, 339 women $(57.5 \%)$ and 4 respondents $(0.7 \%)$ who did not answer the questions. There were 37 people (6.2\%) with completed primary school level of education or less, 345 people (58.1\%) who completed secondary school and 206 $(34,7 \%)$ who finished vocational school level of education or more. There were 6 people (1\%) who did not define their level of education. The average age of respondents is 35.82 years, standard deviation is 9.66 years. The average salary is 935.35 neto euros, standard deviation is 339.95 euros.

Accessories-description questionnaire: The questionnaire consists of twentyone closed-ended questions, three questions relate to demographic data (gender, age, level of education and amount of salary) of respondents. The questionnaire 
was compiled by the authors but the part of the questionnaire for measure employee engagement used UWES-9. This scale, called the Utrecht Work Engagement Scale (UWES) is composed of 9 items and was found to have good psychometric properties, with Cronbach's $\alpha$ generally higher than 0.80 . The UWES-9 (Schaufeli\& Bakker, 2003) questionnaire consists of 9 items: S1. At my work, I feel bursting with energy.S2. At my job, I feel strong and vigorous.S3. I am enthusiastic about my job.S4. My job inspires me.S5. When I get up in the morning, I feel like going to work.S6. I feel happy when I am working intensely.S7. I am proud of the work that I do.S8. I am immersed in my job.S9. I get carried away when I am working. The assessment scale had a 5 points: 6always... 1 -never.

The job satisfaction was measured with 8 items: J1: Satisfaction with the amount of salary. J2: Satisfaction with relations between employees. J3: Satisfaction with the leadership and communication of supervisor. J4: Satisfaction with working condition. J5: Satisfaction with organisation and division of labour. J6: Satisfaction with the top management. J7: Satisfaction with the working time. J8: Satisfaction with the chance of promotion.

Working methods and procedures of measurement: Interviews (face to face) were carried out from 4 January 2016 to 14 March 2016. The authors interviewed friends and acquaintances. Solving questionnaire took about 5 minutes. The authors distributed 620 surveys but only 594 were analysed. 26 surveys were highly incomplete (more than half of the responses in the questions were missing), so the authors excluded them from the further statistical analysis.

Used methods, data processing: The collected data were analysed using IBM SPSS, version 20. We have also used the Microsoft tools Word and Excel. Regarding the purpose and objectives of the research we used ANOVA test and linear regression.

Verification of the adequacy of the measurement instrument: For the measuring employee engagement the authors used UWES-9 questionnaire.

Table 1. Case processing engagement

\begin{tabular}{|c|c|c|}
\hline & $\mathrm{N}$ & $\%$ \\
\hline Valid & 587 & 98.8 \\
\hline Cases excluded & 7 & 1.2 \\
\hline Total & 594 & 100.0 \\
\hline
\end{tabular}

Source: SPSS 20, Author's creation 
Table 2. Reliability Statistics, engagement

\begin{tabular}{|c|c|}
\hline Cronbach's Alpha & N of items \\
\hline 0.914 & 9 \\
\hline
\end{tabular}

Source: SPSS 20, Author's creation

The authors calculated that Cronbach's alpha is equal to 0.914 (Tables 1 and 2) which means a lot or exemplary reliability of measurement employee engagement.

For the measuring job satisfaction the authors used own questionnaire with 8 items.

Table 3. Case processing, job satisfaction

\begin{tabular}{|c|c|c|}
\hline & $\mathrm{N}$ & $\%$ \\
\hline Valid & 589 & 99.2 \\
\hline Cases excluded & 5 & 0.8 \\
\hline Total & 594 & 100.0 \\
\hline
\end{tabular}

Source: SPSS 20, Author's creation

Table 4. Reliability Statistics, job satisfaction

\begin{tabular}{|c|c|}
\hline Cronbach's Alpha & N of items \\
\hline 0.887 & 8 \\
\hline
\end{tabular}

Source: SPSS 20, Author's creation

The authors also calculated that Cronbach's alpha is equal to 0.887 (Tables 13 and 14) for measuring job satisfaction, which means a lot or exemplary reliability of measurement.

\subsection{Factor Analysis and Cronbach's Test for the Gallup Questionnaire}

From 5/1/2012 to $15 / 3 / 2012$, the authors performed a survey of engagement on a sample of respondents and for the measurement of 849 engagements using a Gallup questionnaire. If the factorial analysis using the method of the main components and the method of Varimax rotation are carried out, the following results are obtained which can be seen in Tables 1, 2, 3 and 4 .

Table 2 gives a correlation matrix, which allows the analysis of dependencies between the variables. From the size of the correlation coefficients the authors determine that there is a medium correlation between the variables G2 and G3, between variables G4, G5 and G6, between variables G5 and G7, between variables G6, G4, G5, G7, G11 and G12, and between variables, G5, G7, G3 G6 and G8, G8 and G7, and G6, G11 and G 12. The analysis of dependencies between 
the variables (Table 4) shows the viability of using factor analysis, which confirms a Bartlett's test and sphericity and Kaiser-Meyer-Olkin indicator (KMO). The results of these two tests are given in Table 1 . The value of the pointer is greater than 0.5 and KMO by the risk of less than 0.05 to reject the null hypothesis that the correlation matrix is the same as array unit (Bartlett's test of sphericity).

Table 5. KMO and Bartlett's test for the Gallup questionnaire

\begin{tabular}{|c|c|c|}
\hline \multicolumn{2}{|c|}{ Kaiser-Meyer-Olkin test } & 0,914 \\
\hline \multirow{3}{*}{ Bartlett's Test } & Hi-square & 3959,496 \\
\cline { 2 - 3 } & Df & 66,000 \\
\cline { 2 - 3 } & P-value & 0,000 \\
\hline
\end{tabular}

Source: SPSS 20, Author's creation

Table 6.Correlation matrix between variables measuring the engagement using the Gallup questionnaire

\begin{tabular}{|l|c|r|r|r|r|r|r|r|r|r|r|l|}
\hline & G1 & G2 & G3 & G4 & G5 & G6 & G7 & G8 & G9 & G10 & G11 & G12 \\
\hline G1 & 1 & 0,489 & 0,373 & 0,214 & 0,331 & 0,171 & 0,301 & 0,29 & 0,334 & $-0,032$ & 0,147 & 0,206 \\
\hline G2 & 0,489 & 1 & 0,525 & 0,368 & 0,439 & 0,424 & 0,49 & 0,43 & 0,435 & 0,069 & 0,313 & 0,342 \\
\hline G3 & 0,373 & 0,525 & 1 & 0,434 & 0,442 & 0,44 & 0,517 & 0,465 & 0,429 & 0,144 & 0,365 & 0,405 \\
\hline G4 & 0,214 & 0,368 & 0,434 & 1 & 0,536 & 0,575 & 0,472 & 0,413 & 0,301 & 0,232 & 0,477 & 0,429 \\
\hline G5 & 0,331 & 0,439 & 0,442 & 0,536 & 1 & 0,554 & 0,59 & 0,439 & 0,438 & 0,128 & 0,413 & 0,382 \\
\hline G6 & 0,171 & 0,424 & 0,44 & 0,575 & 0,554 & 1 & 0,59 & 0,426 & 0,362 & 0,235 & 0,562 & 0,523 \\
\hline G7 & 0,301 & 0,49 & 0,517 & 0,472 & 0,59 & 0,59 & 1 & 0,527 & 0,444 & 0,126 & 0,488 & 0,483 \\
\hline G8 & 0,29 & 0,43 & 0,465 & 0,413 & 0,439 & 0,426 & 0,527 & 1 & 0,46 & 0,213 & 0,38 & 0,382 \\
\hline G9 & 0,334 & 0,435 & 0,429 & 0,301 & 0,438 & 0,362 & 0,444 & 0,46 & 1 & 0,125 & 0,323 & 0,336 \\
\hline G10 & $-0,032$ & 0,069 & 0,144 & 0,232 & 0,128 & 0,235 & 0,126 & 0,213 & 0,125 & 1 & 0,315 & 0,207 \\
\hline G11 & 0,147 & 0,313 & 0,365 & 0,477 & 0,413 & 0,562 & 0,488 & 0,38 & 0,323 & 0,315 & 1 & 0,621 \\
\hline G12 & 0,206 & 0,342 & 0,405 & 0,429 & 0,382 & 0,523 & 0,483 & 0,382 & 0,336 & 0,207 & 0,621 & 1 \\
\hline
\end{tabular}

Source: SPSS 20, Author's creation 
Table 7. Eigenvalues and explaining the variance using the Gallup questionnaire

\begin{tabular}{|r|r|r|r|r|r|}
\hline Variable & Eigenvalue & $\begin{array}{c}\text { \% } \\
\text { Variance }\end{array}$ & $\begin{array}{r}\text { Cumulative } \\
\%\end{array}$ & Eigenvalue & $\begin{array}{c}\% \\
\text { Variance }\end{array}$ \\
\hline G1 & 5,317 & 44,312 & 44,312 & 5,317 & 44,312 \\
\hline G2 & 1,358 & 11,317 & 55,63 & 1,358 & 11,317 \\
\hline G3 & 0,853 & 7,109 & 62,739 & & \\
\hline G4 & 0,712 & 5,932 & 68,671 & & \\
\hline G5 & 0,682 & 5,681 & 74,352 & & \\
\hline G6 & 0,573 & 4,772 & 79,124 & & \\
\hline G7 & 0,518 & 4,316 & 83,44 & & \\
\hline G8 & 0,487 & 4,055 & 87,495 & & \\
\hline G9 & 0,447 & 3,728 & 91,224 & & \\
\hline G10 & 0,36 & 3,002 & 94,226 & & \\
\hline G11 & 0,358 & 2,982 & 97,207 & & \\
\hline G12 & 0,335 & 2,793 & 100 & & \\
\hline
\end{tabular}

Source: SPSS 20, Author's creation

In Table 7 the authors present eigenvalues for each factor. The first two factors have an inherent value greater than one. Maximum eigenvalue belongs to the first factor and is equal to 5.317 . It explains $44,312 \%$ of the total variance, the second factor is $11,317 \%$ of the variance. The first two factors explain $55.630 \%$ of the total variance.

With a rotation of factors the authors try to find a simpler structure, therefore, hereinafter referred to using Varimax methods. Changed eigenvalues and the corresponding percentages of the total variance explained are given in Table 8.

By comparing their own values given in Tables 7 and 8 the authors determine that the first factor decreases and increases the other. After the rotation with two factors $55.630 \%$ of the total variance is explained.

Table 8. Eigenvalues and explained variance after rotation using the Gallup questionnaire

\begin{tabular}{|c|r|r|r|r|r|}
\hline Variable & Eigenvalue & $\begin{array}{c}\text { \% } \\
\text { Variance }\end{array}$ & $\begin{array}{c}\text { Cumulative } \\
\%\end{array}$ & $\begin{array}{c}\text { Eigenvalue } \\
\text { after rotation }\end{array}$ & $\begin{array}{c}\text { \% Variance } \\
\text { after rotation }\end{array}$ \\
\hline G1 & 5,317 & 44,312 & 44,312 & 3,529 & 29,409 \\
\hline G2 & 1,358 & 11,317 & 55,63 & 3,146 & 26,220 \\
\hline G3 & 0,853 & 7,109 & 62,739 & & \\
\hline G4 & 0,712 & 5,932 & 68,671 & & \\
\hline
\end{tabular}




\begin{tabular}{|l|r|r|r|l|l|}
\hline G5 & 0,682 & 5,681 & 74,352 & & \\
\hline G6 & 0,573 & 4,772 & 79,124 & & \\
\hline G7 & 0,518 & 4,316 & 83,44 & & \\
\hline G8 & 0,487 & 4,055 & 87,495 & & \\
\hline G9 & 0,447 & 3,728 & 91,224 & & \\
\hline G10 & 0,36 & 3,002 & 94,226 & & \\
\hline G11 & 0,358 & 2,982 & 97,207 & & \\
\hline G12 & 0,335 & 2,793 & 100 & & \\
\hline
\end{tabular}

Source: SPSS 20, Author's creation

Table 9. The factor weights derived from the Varimax method using the Gallup questionnaire

\begin{tabular}{|c|r|r|}
\hline \multirow{2}{*}{ Variable } & \multicolumn{2}{|c|}{ Factors } \\
\cline { 2 - 3 } & \multicolumn{1}{|c|}{1} & \multicolumn{1}{c|}{2} \\
\hline G1 & 0,758 & $-0,146$ \\
\hline G2 & 0,773 & 0,158 \\
\hline G3 & 0,667 & 0,322 \\
\hline G4 & 0,378 & 0,626 \\
\hline G5 & 0,593 & 0,447 \\
\hline G6 & 0,391 & 0,704 \\
\hline G7 & 0,609 & 0,502 \\
\hline G8 & 0,56 & 0,411 \\
\hline G9 & 0,635 & 0,238 \\
\hline G10 & $-0,168$ & 0,617 \\
\hline G11 & 0,224 & 0,778 \\
\hline G12 & 0,314 & 0,668 \\
\hline
\end{tabular}

Source: SPSS 20, Author's creation

In this case, the variables G1, G2, G3, G5, G7, G8 and G9 have high factor weights for the first factor (Table 5). These variables therefore clarify the content of the first factor, which explains the rotation $29.409 \%$ of the total variance. Considering the content of these variables, the first factor should be called the conditions of work and the appreciation of the individual. Variables G4, G6, G10, G11 and G12 have high factor weights for the second factor. It should be called the 
management and development of the individual. This factor explains $26.220 \%$ of the total variance.

The authors calculated that Cronbach's alpha is 0.875 (Table 10) which means a lot or exemplary reliability of measurement.

Table 10. Reliability Statistics, Gallup questionnaire

\begin{tabular}{|c|c|}
\hline Cronbach's Alpha & N of items \\
\hline 0.875 & 12 \\
\hline
\end{tabular}

Source: SPSS 20, Author's creation

The alpha coefficient for the twelve items is 0.875 , suggesting that the items have relatively high internal consistency.

\subsection{Factor Analysis and Cronbach's Test for UWES-9 Questionnaire}

During the period from 6 December 2013 to 31 January 2014, the authors performed a survey based on UWES-9 methodology on a sample of 281 respondents. If factor analysis using the principal component method and Varimax rotation are reperformed, the following results are obtained, which are shown in Tables 11, 12 and 3.

Table 12 gives correlation matrix between variables. From the size of the correlation coefficients there can be seen a medium strong correlation between all the variables. If the value of the $\mathrm{KMO}$ is greater than 0.5 and the risk is lesser than 0.05 the authors cannot reject the null hypothesis that the correlation matrix is equal to the unit matrix (Bartlett's sphericity test).

Table 11. KMO and Bartlett's test for UWES-9 questionnaire

\begin{tabular}{|c|c|c|}
\hline \multicolumn{2}{|c|}{ Kaiser-Meyer-Olkin test } & 0,940 \\
\hline \multirow{3}{*}{ Bartlett's Test } & Hi-square & 1732,162 \\
\cline { 2 - 3 } & Df & 36,000 \\
\cline { 2 - 3 } & P-value & 0,000 \\
\hline
\end{tabular}

Source: SPSS 20, Author's creation, 
Table 12.Correlation matrix between variables measuring the engagement using the UWES-9 questionnaire

\begin{tabular}{|c|c|c|c|c|c|c|c|c|c|}
\hline & S1 & S2 & S3 & S4 & S5 & S6 & S7 & S8 & S9 \\
\hline S1 & 1 & 0,592 & 0,585 & 0,615 & 0,556 & 0,501 & 0,634 & 0,527 & 0,564 \\
\hline S2 & 0,592 & 1 & 0,681 & 0,546 & 0,645 & 0,543 & 0,661 & 0,666 & 0,579 \\
\hline S3 & 0,585 & 0,681 & 1 & 0,616 & 0,668 & 0,685 & 0,656 & 0,585 & 0,656 \\
\hline S4 & 0,615 & 0,546 & 0,616 & 1 & 0,581 & 0,644 & 0,616 & 0,525 & 0,663 \\
\hline S5 & 0,556 & 0,645 & 0,668 & 0,581 & 1 & 0,62 & 0,66 & 0,643 & 0,58 \\
\hline S6 & 0,501 & 0,543 & 0,685 & 0,644 & 0,62 & 1 & 0,61 & 0,54 & 0,719 \\
\hline S7 & 0,634 & 0,661 & 0,656 & 0,616 & 0,66 & 0,61 & 1 & 0,684 & 0,655 \\
\hline S8 & 0,527 & 0,666 & 0,585 & 0,525 & 0,643 & 0,54 & 0,684 & 1 & 0,57 \\
\hline S9 & 0,564 & 0,579 & 0,656 & 0,663 & 0,58 & 0,719 & 0,655 & 0,57 & 1 \\
\hline
\end{tabular}

Source: SPSS 20, Author's creation

Table 13.Eigenvalues and explain the variance using the UWES-9 questionnaire

\begin{tabular}{|c|c|c|c|c|c|}
\hline Variable & Eigenvalue & $\begin{array}{c}\% \\
\text { Variance }\end{array}$ & $\begin{array}{c}\text { Cumulative } \\
\%\end{array}$ & Eigenvalue & $\begin{array}{c}\% \\
\text { Variance }\end{array}$ \\
\hline S1 & 5,91076 & 65,6751 & 65,6751 & 5,91076 & 65,6751 \\
\hline S2 & 0,65486 & 7,27624 & 72,95134 & & \\
\hline S3 & 0,53533 & 5,948148 & 78,89948 & & \\
\hline S4 & 0,40933 & 4,548106 & 83,44759 & & \\
\hline S5 & 0,36814 & 4,090459 & 87,53805 & & \\
\hline S6 & 0,32597 & 3,621917 & 91,15997 & & \\
\hline S7 & 0,28239 & 3,137687 & 94,29765 & & \\
\hline S8 & 0,487 & 4,055 & 87,495 & & \\
\hline S9 & 0,447 & 3,728 & 91,224 & & \\
\hline
\end{tabular}

Source: SPSS 20, Author's creation

In Table 13, the authors present eigenvalues only to a single factor. The first factor has the inherent value greater than one and is equal to 5.91076. It explains $65.675 \%$ of the total variance. Since then the authors have gotten only one factor, which means that the questionnaire is very tenaciously for measuring employee engagement, and that cannot be carried out hereinafter referred to as the Varimax method. 
The authors calculate that Cronbach's alpha is 0.932 (Table 14) which means a lot or exemplary reliability of measurement.

Table 14. Reliability Statistics, UWES-9 questionnaire

\begin{tabular}{|c|c|}
\hline Cronbach's Alpha & N of items \\
\hline 0,932 & 9 \\
\hline
\end{tabular}

Source: SPSS 20, Author's creation

The alpha coefficient for the nine items is 0.932, suggesting that the items have relatively high internal consistency.

\subsection{Findings of the Research-Test Hypotheses}

The first hypothesis was tested with a model of linear regression. In the Model the authors chose independent variables $\mathrm{X}$-EE. The independent variable was measured as the sum of 9 factors by UWES-9. The dependent variable (Y-JS) was measured as the sum of 8 factors.

The linear regression Model (1) with estimated parameters is:

$$
(\widehat{Y}=9.52+0.545 \mathrm{X})
$$

$\mathrm{n}=584$, R-squared $=0.581$, Adjusted R-squares $=0.337$, Standard Error $=$ 6.79. In Model (Table 15, 16, 17) $33.7 \%$ of total sum of squares are explained by the estimated model. Variables $X$ (p-value $=0.000$ ) is statistically significant. The first hypothesis is accepted.

Table 15. Regression Model: $K=1, n=584$

\begin{tabular}{|c|c|c|c|}
\hline $\mathrm{R}$ & $\mathrm{R}$ Square & $\begin{array}{c}\text { Adjusted } \mathrm{R} \\
\text { Square }\end{array}$ & $\begin{array}{c}\text { Std. Error of the } \\
\text { Estimate }\end{array}$ \\
\hline 0.581 & 0.337 & 0.336 & 6.79038 \\
\hline
\end{tabular}

Source: SPSS 20, Author's creation

Table 16. Regression Model, F-test

\begin{tabular}{|c|c|c|c|c|}
\hline Model & Sum of Squares & df & F & Sig. \\
\hline Regres. & 13654.905 & 1 & 296,142 & 0.000 \\
\hline Resid. & 26835.600 & 582 & & \\
\hline Total & 40490.505 & 583 & & \\
\hline
\end{tabular}

Source: SPSS 20, Author's creation 
Table 17. Regression Model: $K=1, n=584$

\begin{tabular}{|c|c|c|c|c|}
\hline & Coeff. & $\begin{array}{c}\text { Standard } \\
\text { Error }\end{array}$ & $\mathrm{t}$ - Stat & P-value \\
\hline Inter. & 9.525 & 1.235 & 54.83 & 0.000 \\
\hline $\mathrm{X}$ & 0.545 & 0.032 & 0.195 & 0.000 \\
\hline
\end{tabular}

Source: SPSS 20, Author's creation

The second hypothesis states that there is a statistically significant difference in the employee engagement between genders. The hypothesis was checked by ANOVA test.

Table 18. Test ANOVA-Employee engagement and gender

\begin{tabular}{|c|c|c|c|c|c|}
\hline & $\begin{array}{c}\text { Sum of } \\
\text { Squares }\end{array}$ & df & $\begin{array}{c}\text { Mean } \\
\text { Square }\end{array}$ & F & P-value \\
\hline $\begin{array}{c}\text { Between } \\
\text { Groups }\end{array}$ & 279.001 & 1 & 279.001 & 3.604 & 0.058 \\
\hline $\begin{array}{c}\text { Within } \\
\text { Groups }\end{array}$ & 44976.810 & 581 & 77.413 & & \\
\hline Total & 45255.811 & 582 & & & \\
\hline
\end{tabular}

Source: IBM SPSS 20, Excel, Author's creation

Table 18 shows $(\mathrm{F}(1,582)=3.604, \mathrm{p}$-value $=0.058)$, that there is no statistically significant difference between gender and employee engagement. Therefore, the hypothesis is rejected.

The last hypothesis states that there is a statistically significant difference in the job satisfaction between genders. The hypothesis was checked by ANOVA test.

Table 19. Test ANOVA-Job satisfaction and gender

\begin{tabular}{|c|c|c|c|c|c|}
\hline & $\begin{array}{c}\text { Sum of } \\
\text { Squares }\end{array}$ & $\mathrm{df}$ & $\begin{array}{c}\text { Mean } \\
\text { Square }\end{array}$ & $\mathrm{F}$ & P-value \\
\hline $\begin{array}{c}\text { Between } \\
\text { Groups }\end{array}$ & 108.055 & 1 & 108.055 & 1.566 & 0.211 \\
\hline $\begin{array}{c}\text { Within } \\
\text { Groups }\end{array}$ & 40224.184 & 583 & 68.995 & & \\
\hline Total & 40332.239 & 584 & & & \\
\hline
\end{tabular}

Source: IBM SPSS 20, Excel, Author's creation

Table 19 shows $(\mathrm{F}(1,584)=1.566$, $\mathrm{p}$-value $=0.211)$, that there is no statistically significant difference between gender and job satisfaction. Therefore, the hypothesis is also rejected. 


\section{Conclusion}

In this paper the authors investigate the relationship between employee engagement (X-EE) and the dependent variable $\mathrm{Y}$ - job satisfaction.

In our research, the authors find out that there is a positive relationship between employee engagement and job satisfaction.

Linear regression Model, with $\mathrm{n}=584$ and $\mathrm{K}=1$ regressor, indicates that variables $X$ are statistically significant at $5 \%$ significance level. The regression coefficient $\beta=0.545$ shows (Table 7 ) that if $X$-employee engagement would increase, the regression value of job satisfaction would also increase. On the other side, the authors find out that there is no statistically significant difference between gender and employee engagement and job satisfaction.

In further research it would be interesting to use more independent variables such as age, level of education, amount of salary etc in linear model.

$$
\text { Employee engagement }=\mathrm{f}(+\mathrm{job} \text { satisfaction })
$$

\section{References}

Barling, J., Kelloway, E. K. and Iverson, R. D. (2003). Journal of Applied Psychology, Vol 88(2), Apr 2003, 276-283.

Brief, A. P., \&Weiss, H. M. (2002). Organizational behavior: Affect in the workplace. Annual Review of Psychology, 53, 279-307.

Employee Engagement Research Report Update-January 2013, Retrieved from: http://www.blessingwhite.com/eee_report.asp, Accessed on 30March 2016.

Employee Engagement, Retrieved from: http://www.talentkeepers.com/engagement.jsp, Accessed on 10April 2016.

Kahn, W. A. (1990). Psychological conditions of personal engagement and disengagement at work. Academy of Management Journal, 33 (4), 692-724.

Fleisher, C., Khapova, N. S. in Jansen, P. G. W. (2014) "Effects of employees' career competencies development on their organizations: Does satisfaction matter?",Career Development International, 19 (6), 700-717.

Grandey, A. (2000). Emotion regulation in the workplace: A new way to conceptualize emotional labor. Journal of Occupational Health Psychology, 5(1), 95-110.

Harter, J. K., Schmidt, F. L., \& Hayes, T. L. (2002). Business-unit-level relationship between employee satisfaction, employee engagement, and business outcomes: A meta-analysis. Journal of Applied Psychology, 87(2), 268-279.

Harter, J. K., Schmidt, F. L., Killham, E. A., \&Asplund, J. W. (2006).Q12 MetaAnalysis.Retrieved from: https://strengths.gallup.com/private/resources/q12metaanalysis_flyer_gen_08\%2008_bp.pdf.

Judge, T. A. in Bono, J. E. (2001).Relationshipofcoreself-evaluations traits—self-esteem, generalizedself-efficacy, locusofcontrol, and emotional stabilitywithjobsatisfactionandjobperformance: A meta-analysis. American Psychological Association, 86. 
Landy, F. J. in Conte, J. M. (2007). Work in the 21st Century. An Introduction to Industrial and Organizational Psychology. Personal Psychology, 61 (2), 447-450.

Lee, T. Y. (2006). Expectations of employees toward the workplace and environmental satisfaction, Facilities, 24 (9/10), 343-353.

Maslach, C., Schaufelli, W. B. and Leiter, M. P. (2001) Job burnout. Annual Review of Psychology, 52, 397-422.

Pogačnik, V. (2002).Lestvicaosebnihvrednot. Ljubljana: Center zapsihodiagnostičnasredstva.

Q12 ${ }^{\circledR}$ Meta-Analysis. The Relationship between Engagement at Work and Organizational Outcomes, Retrieved from: http://www.gallup.com/strategicconsulting/126806/Q12Meta-Analysis.aspx,Accessed on 14April 2016.

Rathi, N. (2011). Psychological Well-Being and Organizational Commitment: Exploration of the Relationship. Working Paper No.106/2011, Retrieved from:http://www.amrita.edu/sdg/pdf/ASB\%20Working\%20paper\%20series/MBA\% 20book\%20106-2011\%20Psychological\%20Well-

Being\%20and\%20Organizational\%20Commitment\%20Exploration\%20of\%20the\% 20Relationship.pdf, Accessed on 6 August 2016.

Roethlisberger, F. J., \& Dickson, W. J. (1939). Management and the Worker: An Account of a Research Program Conducted by the Western Electric Company. Chicago: Cambridge, Mass: Harward University Press.

Saks, A. M. (2006). Antecedents and consequences of employee engagement. Journal of Managerial Psychology, 21 (7), 600-619.

Semih T. in Tugba Z., (2016).Social interactions in job satisfaction", International Journal of Manpower, 37 (3), 426-455.

Shanmuga, P., \&Vijayadurai, J. ( 2014). Employee Engagement in Organisations. European Journal of Business and Management(Department of Management studies, BharathNiketan Engineering College, Andipatty), Vol. 6, No. 34.

Schaufeli, W.B., Bakker, A.B. and Salanova, M. (2006). The measurement of work engagement with a short questionnaire: a cross-national study. Educational and Psychological Measurement, 66 (4), 701-716.

Schaufeli, W.B., Salanova, M., Gonzalez-Roma, V. and Bakker, A.B. (2002). The measurement of engagement and burnout and: a confirmative analytic approach. Journal of Happiness Studies, 3, 71-92.

Schneider, B., Hanges, P. J., Smith, D. B., \&Salvaggio, A. N. (2003). Which comes first: Employee attitudes or organizational financial and market performance? Journal of Applied Psychology, 88, 836-851.

Smsdieta, Retrieved from:http://www.smsdieta.si/indeks-telesne-mase/, Accessed on 14 September 2016.

Vorina, A. (2013). The relationship between satisfaction with life and employee engagement. Journal of Process Management - New Technologies, International, 1 (2), 77-81.

Vorina, A., David, K. and VrabičVukotić, A. (2013).The relationship between the development of the ict competencies and employee engagement.Vesnik, 2 (1), 3750 .

Warr, P., \&Inceoglu, I. (Apr 2012). Job engagement, job satisfaction, and contrasting associations with person-job fit. Journal of Occupational Health Psyhology, Vol 17(2), 129-138. 


\section{ANALIZA ODNOSA IZMEĐU ZADOVOLJSTVA POSLOM I ANGAŽOVANJA RADNIKA}

Apstrakt: Ovaj rad ispituje odnos između angažovanja zaposlenih i zadovoljstva poslom. Ljudi provode većinu vremena na poslu, a njihova motivacija se smatra važanim faktorom za obavljanje posla. Radnici entuzijasti, koji fokusiraju svoje napore na postizanje ciljeva svojih kompanija, su ključna konkurentna prednost u savremenom svetu. Efekat angažovanja zaposlenih na poslovanje je proučavana od strane raznih stručnjaka. Došli su do sličnog zaključka-što više entuzijazma radnici imaju, bolji rezultati poslovanja se postižu za kompaniju. Uzorak od 594 ispitanika koji su zaposleni u javnom i van javnog sektora u Sloveniji je korišćen za potrebe ove studije. Glavni cilj ovog istraživanja je da se utvrdi da li (i koliko) angažovanje radnika utiče na zadovoljstvo poslom. Istraživanje je sprovedeno od 4. januara 2016. do 14. marta 2016. godine gde je korišćen IBM SPSS 20 za statističku analizu. Rezultati potvrđuju da je odnos između angažovanja zaposlenih i zadovoljstva poslom pozitivan i statistički značajan ( $5 \%$ značaj nivo), na osnovu linearne regresije $\mathrm{F}(1,583)=296.14, \mathrm{p}$-vrednost $=0.000, \mathrm{R}$ kvadrat $=0,337$. Rezultati takođe pokazuju da ne postoji statistički značajna razlika između angažovanja radnika i roda i ne postoji statistički značajna razlika između zadovoljstva poslom i roda.

Ključne reči: radnik, angažman, zadovoljstvo poslom, linearna regresija, faktorska analiza.

\section{Authors' biographies}

Anton Vorina is Lecturer at Vocational College in Celje. He has finished four different faculties (Faculty of Mechanical Engineering, Faculty of Economics, Master of Quality Management and Ph.D. in Business and Commerce. Teaching and research interests include Management of Quality, Logistics, Motivation of employee, etc. He is presently involved in research on quality in tourism, engagement of employee and the leadership of companies. He has been associated with projects in many companies in Slovenia about optimising the costs. Research efforts have resulted into more than 90 scientific papers. He has authored more than 10 books and is supervising more than 400 undergraduate theses. He is also visiting lecturer.

Miro Simonič is Lecturer at the High School of Economics in MurskaSobota, where he teaches the subject the Design of Products and Business Processes and Business Logistics. As a guest lecturer he also conducts lectures at the Faculty of Commercial and Business Sciences (FKPV) in Celje, where he also received his Master's degree and successfully defended his doctoral dissertation. He is permanently employed in the company PerutninaPtuj, where he has accumulated many years of practical experience in the field of sales and marketing. He is responsible for design of new products and the sale 
of products on the markets of Switzerland, Germany, MCD, Slovakia and Hungary. He has published several papers at conferences with research on consumer behaviour, healthy food, environment protection and marketing.

Maria Vlasova is a student at Russian Customs Academy. She holds a Master's degree in customs service management. She also graduated from Moscow State Technological University, Faculty of Economics, Finances and Credit, where she obtained a Bachelor's Degree. 